\title{
The Design of the Swiss Feed-In Tariff
}

\author{
Policy Transfer and Accommodation
}

\author{
Leonore Haelg, Tobias S. Schmidt, and Sebastian Sewerin
}

\begin{abstract}
Contents

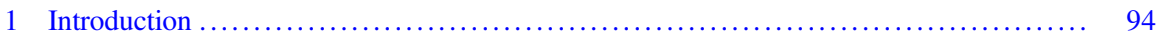

2 Review of the Policy Diffusion and Transfer Literatures ........................ 97

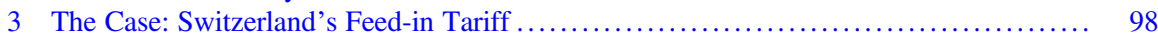

3.1 Comparing the Swiss and German RE Policies ......................... 98

3.2 Method and Sampling ........................................... 100

4 Evolution of the Feed-In Tariff Design in Germany and Switzerland .................. 100

$4.1 \quad$ Feed-In Tariff Implementation . . .................................... 101

4.2 Feed-In Tariff Designs Specific to Individual Technologies ..................... 104

5 Discussion and Conclusion ................................................ 109

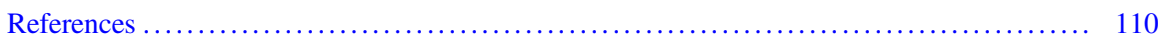

\begin{abstract}
In light of climate change mitigation and the transformation of the energy sector, many jurisdictions have adopted deployment policies for renewable energy (RE) technologies. Several RE deployment policy instruments have diffused from frontrunner countries to other jurisdictions. Switzerland implemented its first comprehensive RE support policy with the adoption of a cost-covering and technologyspecific feed-in tariff in 2009, following Germany's example. Yet, policy designs look very different in the two countries and, importantly, also result in different policy outcomes. In this chapter, we examine the reasons for these policy design differences. We unpack the design of the Swiss feed-in tariff and analyze which of the policy's elements were directly adopted from Germany and which were accommodated to the Swiss context and why. In particular, we compare the specific instrument designs for two renewable power generation technologies, solar
\end{abstract}

\section{Haelg $(\square)$}

ETH Zurich, Energy Politics Groups, Department of Humanities, Social and Political Sciences,

Zurich, Switzerland

e-mail: leonore.haelg@zhaw.ch

T. S. Schmidt · S. Sewerin

Zurich University of Applied Sciences (ZHAW), Research Group for Renewable Energy,

Institute of Natural Resource Sciences, Wädenswil, Switzerland

e-mail: sebastian.sewerin@gess.ethz.ch 
photovoltaics (PV) and biomass, and study the role of technology-related actors in shaping these policy designs. We draw from the policy diffusion and policy transfer literatures and offer important extensions to the literature by showing that, instead of entire policies, it is possible that only certain design elements of a policy diffuse from one jurisdiction to another. Additionally, we find that the composition of the existing technology-related actor bases in the donor and recipient countries is important in determining whether the accommodation of the design elements to the domestic context occurs.

\section{Introduction}

Climate change mitigation requires the implementation of new policies to incentivize innovation in and the deployment of low-carbon energy technologies. Besides carbon pricing (addressing the negative pollution externality), R\&D support policies and deployment policies for clean technologies should be part of this policy mix to address the various positive innovation externalities. ${ }^{1}$ Frontrunner countries therefore started experimenting with technology deployment policies as early as the 1990s. These policy schemes have the goal of creating demand for novel technologies, such as renewable energy (RE) technologies, by increasing incentives for investments in these technologies. ${ }^{2}$ For instance, the UK implemented the Non-Fossil Fuel Obligation in 1990, which offered RE technologies the possibility to compete for a premium price per unit of generated electricity. ${ }^{3}$ Another example is RE standards, which were adopted by a number of US states in the 1990s and which require electricity suppliers to source a specific quantity of electricity from RE sources. ${ }^{4}$

Swiss policymakers did not remain dormant in this early phase of RE policy support. In 1991, they implemented an early version of an RE feed-in tariff. ${ }^{5}$ A feedin tariff supports RE deployment by offering guaranteed grid access as well as longterm and cost-covering remuneration of the generated electricity. ${ }^{6}$ Yet, the 1991 feed-in tariff in Switzerland only offered grid access and a tariff on the basis of the avoided cost of conventional power plants rather than covering the cost incurred by RE electricity generation. In doing so, the instrument was designed to promote the deployment of small-scale hydropower and did so somewhat successfully. Other RE

\footnotetext{
${ }^{1}$ Jaffe et al. (2005); Van Benthem et al. (2008); Lehmann, Söderholm (2018).

${ }^{2}$ Schmidt et al. (2016).

${ }^{3}$ Mitchell (2000).

${ }^{4}$ Wiser et al. (2007); Carley et al. (2018).

${ }^{5}$ Haelg et al. (2020).

${ }^{6}$ Jacobs (2014).
} 


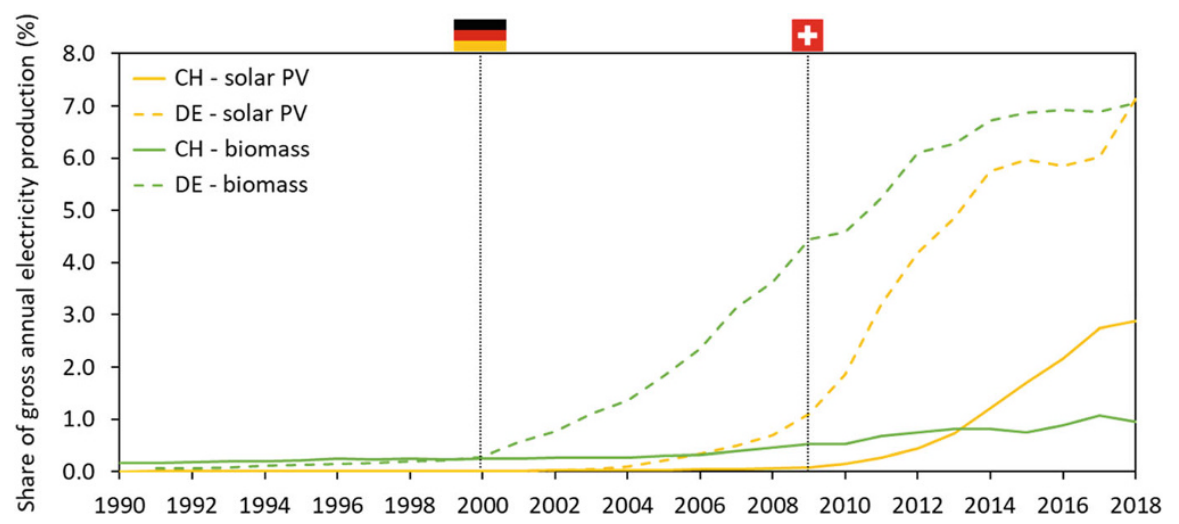

Fig. 1 Share of gross annual electricity production of the two RE technologies, solar PV (in yellow) and biomass (in green), in Germany (dashed line) and Switzerland (solid line). The dotted lines and flags represent the implementation year of the comprehensive feed-in tariff in the respective country. Data sources: BMWi (2019); Swiss Federal Office of Energy (2019)

technologies did not experience substantial capacity additions under this early feedin tariff scheme.

Since the early 2000s, the number of jurisdictions that implemented RE deployment policies increased considerably. The most popular policy instrument at that time was the feed-in tariff. ${ }^{7}$ The rise in policy support was followed by a surge in RE investments. ${ }^{8}$ Germany, as one of the first countries to implement a comprehensive feed-in tariff (Erneuerbare-Energien-Gesetz EEG) in 2000, represents a frontrunner in RE capacity additions, specifically for solar photovoltaics (PV). Given the German policy's high effectiveness, more jurisdictions followed suit and also adopted feed-in tariffs. In Switzerland, where the development of non-hydro RE technologies was still very limited in the early 2000s, the process of completely revising the RE support policy was started in 2004 and finalized in 2009 with the implementation of a cost-covering, technology-specific feed-in tariff (kostendeckende Einspeisevergütung KEV) based on the German example. ${ }^{9}$

Even though many jurisdictions adopted the same RE support instrument, the policy instrument designs between these jurisdictions featured important differences. These design differences affected the respective policies' outcomes regarding RE deployment rates, which look very dissimilar in comparison. Particularly striking are the differences between Switzerland and Germany, which both implemented a feedin tariff (see examples in Fig. 1). In Germany, biomass was already deployed before the EEG adoption but subsequently saw an increase in the deployment rate, while solar PV took off in terms of capacity additions after the EEG amendment in 2004,

\footnotetext{
${ }^{7}$ REN21 (2005).

${ }^{8}$ REN21 (2012).

${ }^{9}$ Haelg et al. (2020); see also Heselhaus (2021).
} 
when generous tariffs for rooftop solar PV were introduced. ${ }^{10}$ Conversely, in Switzerland, RE deployment could not keep up with the dynamics seen in Germany. No new RE technology, including biomass and solar PV, could secure substantial capacity additions. The same applies to onshore wind, where the difference between the two countries is even more pronounced. In 2018, the onshore wind generation amounted to $14.3 \%$ and $0.18 \%$ in Germany and Switzerland, respectively. Here, we do not consider the case of onshore wind, as it is largely influenced by institutional differences between the two countries: while wind farms experience opposition in both countries, ${ }^{11}$ local citizens have many more and stronger possibilities to delay or completely halt wind projects in Switzerland.

These diverging trends between the two countries find a theoretical underpinning in the existing innovation literature, which argues that, more than the policy instrument type itself, the specific instrument design is often decisive for a policy's effectiveness. ${ }^{12}$ Besides the instrument choice, the policy design includes specific policy settings and instrument calibrations, which represent the specific formulation and implementation of a policy. ${ }^{13}$ For instance, while the feed-in tariff is a policy instrument, it includes specifications about which technologies are eligible to receive the tariff as well as the tariff's monetary value, which represent the policy's more specific design elements. ${ }^{14}$

In this chapter, we examine the reasons for the different policy designs in Germany and Switzerland. To do so, we unpack the design of the Swiss feed-in tariff and analyze which of the policy's elements were directly adopted from Germany and which were accommodated to the Swiss context and why. In particular, we compare the specific instrument designs for two renewable power generation technologies, solar PV and biomass, and study the role of technology-related actors in shaping these policy outputs. We draw from the policy diffusion and policy transfer literatures and offer important extensions to these literature streams by showing that, instead of entire policies, it is possible that only certain elements of a policy diffuse from one jurisdiction to another. We therefore invite policy diffusion and policy transfer scholars to take a design perspective in future research. The chapter also has direct implications for policymakers concerned with technologyrelated policy designs. In Switzerland, where additional low-carbon technology policies can be expected to be adopted soon in other sectors, such as mobility, heating, and carbon-intensive industries, policymakers will likely draw from experiences abroad. This chapter's findings may help identify on a more general level which type of design elements may be directly adopted and which are likely to be accommodated to the specific context.

\footnotetext{
${ }^{10}$ Hoppmann et al. (2014).

${ }^{11}$ Ebers and Wüstenhagen (2017); Sonnberger and Ruddat (2017).

${ }^{12}$ E.g., Kemp and Pontoglio (2011); Haelg et al. (2018); Polzin et al. (2019).

${ }^{13}$ Cashore and Howlett (2007).

${ }^{14}$ Haelg et al. (2018).
} 


\section{Review of the Policy Diffusion and Transfer Literatures}

In this chapter, we draw from the policy diffusion and transfer literatures. The two are closely related in that they both analyze how policies spread across jurisdictions. ${ }^{15}$ The policy diffusion literature focuses on the quantitative analysis of the drivers of policy spread across many jurisdictions, particularly studying structural factors, such as domestic institutions, political systems, and economic circumstances. ${ }^{16}$ The policy transfer literature qualitatively analyzes the process by which experiences of and knowledge about a policy in one jurisdiction influence policymaking in another jurisdiction, mainly moderated by transnational or domestic agents. ${ }^{17}$ The policy diffusion and transfer literatures overlap at the intersection of the structural factors and the involved agents, which are interdependent and exert influence on each other, ${ }^{18}$ as well as the mechanisms responsible for a policy being adopted by many jurisdictions. ${ }^{19}$

With climate change and related environmental issues becoming more pressing, the literature on environmental and energy policies and their diffusion has seen substantial additions. ${ }^{20}$ These studies' main focus lies on macro-level characteristics and processes, such as the type of diffusing instruments, ${ }^{21}$ the drivers for the diffusion of specific instruments, ${ }^{22}$ and the instrument characteristics fostering their diffusion. ${ }^{23}$ However, these studies remain unclear about the specific designs of policy instruments. ${ }^{24}$ In other words, how micro-level policy instrument design diffuses or is accommodated to the local context is underexplored. ${ }^{25}$ This is particularly surprising in light of the above outlined differences in policy outcomes between jurisdictions and the literature pointing toward policy design as being decisive in influencing these outcomes. Only Biesenbender and Tosun ${ }^{26}$ address this gap by analyzing the adoption and subsequent modifications of NOx emission standards in OECD countries. They find that different diffusion mechanisms are at play when a policy is newly adopted and when it is subsequently accommodated to the domestic context and that parliamentarians and their party affiliations have an effect on the willingness to adopt a new policy.

\footnotetext{
${ }^{15}$ Newmark (2002); Marsh and Sharman (2009).

${ }^{16}$ Gilardi and Füglister (2008); Berry and Berry (2014); Jordan and Huitema (2014).

${ }^{17}$ Dolowitz and Marsh (1996); Benson and Jordan (2011).

${ }^{18}$ Matisoff (2008); Marsh and Sharman (2009).

${ }^{19}$ Braun and Gilardi (2006).

${ }^{20}$ E.g., Tews et al. (2003); Holzinger et al. (2011).

${ }^{21}$ Stoutenborough (2008); Stadelmann and Castro (2014).

${ }^{22}$ E.g., Strebel (2011); Matisoff and Edwards (2014); Schaffer and Bernauer (2014).

${ }^{23}$ Busch et al. (2005).

${ }^{24}$ Jordan and Huitema (2014).

${ }^{25}$ Biesbroek et al. (2010); Biesenbender and Tosun (2014).

${ }^{26}$ Biesenbender and Tosun (2014).
} 
We build on this finding but expand this understanding about the adoption and accommodation processes regarding the specific design elements of a policy instrument. Additionally, we include a perspective on the role of parliamentarians but also of other actors active in the policymaking process, such as interest groups. We follow Biesenbender and Tosun ${ }^{27}$ and define policy accommodation as "a process of adapting a policy innovation to a domestic institutional and policy context". ${ }^{28}$ While the role of interest groups in policymaking, including the implementation of environmental policies, comprises an entire branch of literature, ${ }^{29}$ their influence on the specific instrument design ${ }^{30}$ as well as the role of policy diffusion is underexplored.

Here, we intend to fill this research gap by analyzing how and why the design of a diffused policy instrument is accommodated upon and after its adoption with a specific focus on the effects of local technology-related actors, namely technology suppliers and technology users, on the process of designing the policy instrument. We analyze technology deployment policies because they are a type of environmental policy considered greatly effective in incentivizing investments in RE technologies $^{31}$ and because technology-related actors are highly important in this policy field as well as for other sectors that need to be decarbonized, such as transport, heating, and carbon-intensive industries.

\section{The Case: Switzerland's Feed-in Tariff}

We use inductive qualitative case study research ${ }^{32}$ to unpack the design elements of the Swiss feed-in tariff and to analyze how policy transfer and accommodation played out.

\subsection{Comparing the Swiss and German RE Policies}

We conduct an in-depth analysis of the Swiss feed-in tariff (KEV), comparing the cases of two renewable power generation technologies, solar PV and biomass. ${ }^{33}$

\footnotetext{
${ }^{27}$ Biesenbender and Tosun (2014).

${ }^{28}$ Biesenbender and Tosun (2014), p. 424.

${ }^{29}$ E.g., Cheon and Urpelainen (2013); Markard et al. (2016); Jacobsson and Lauber (2006); Dumas et al. (2016).

${ }^{30}$ To our knowledge, Stokes (2013) and Haelg et al. (2020) are the only studies analyzing how politics can influence policy instrument design.

${ }^{31}$ Couture and Gagnon (2010).

${ }^{32}$ Eisenhardt (1989).

${ }^{33}$ In our analysis, we only look at biomass power generation from resources such as wood, agricultural waste, etc. Hence, we exclude the feed-in tariffs provided for power from waste incineration and landfill and sewage gas. For Switzerland, the analyzed resource here is "other
} 
Specifically, we study how the feed-in tariff instrument has diffused from Germany to Switzerland and how and why its design has undergone accommodations due to the influence of technology-related actors. We limit the analysis to the revision of the Energy Act (Energiegesetz EnG) adopted by the Swiss parliament in 2007 and implemented in 2009 and the corresponding Energy Ordinance (Energieverordnung $E n V$ ), which were superseded by a new act and a new ordinance in 2018, following the parliamentary debate and the referendum on the Energy Strategy 2050 on May $21,2017$.

These cases are particularly suited for several reasons: First, the feed-in tariff is an instrument type that can easily be tailored to differentiate between technologies or applications by offering them different tariffs. ${ }^{34}$ By analyzing the feed-in tariff design for different technologies, we can perform a comparative case study with different actors involved in the policymaking process ceteris paribus.

Second, Germany was the first country to introduce a technology-specific feed-in tariff in 2000. In the following, the instrument has diffused to many countries. ${ }^{35}$ Switzerland implemented its feed-in tariff only recently in 2009 and has largely drawn from frontrunner countries, such as Germany. Moreover, both countries already implemented a technology-neutral feed-in tariff in the $1990 \mathrm{~s},{ }^{36}$ mainly to trigger the construction of small hydropower plants, and therefore had equal opportunity to learn from this early version of the later policy instrument. Yet, besides these similarities, the specific design of the technology-specific feed-in tariff has proven to be different in Germany and Switzerland in terms of application specificity and subtechnology specificity.

Third, the rationale for the technology selection is based on the different initial industry and technology user environments in Germany and Switzerland, allowing for the analysis of different actor bases. While in the field of biomass, the two countries have shown similarities in terms of technology suppliers, fuel suppliers, and the technological demand to employ agricultural residues even before the policy's implementation, this was different for solar PV. In the 1990s, several firms were already active in solar PV cell production in Germany, ${ }^{37}$ leading to a $30 \%$ share of the solar PV cell production in Europe by $2000 .^{38}$ Additionally, German firms have also been highly active in solar PV module production. Switzerland, conversely, has never been host to a substantial solar PV cell production industry, and before the implementation of the feed-in tariff, only a few firms were

\footnotetext{
biomass" (übrige Biomasse) (EnV 2011). For Germany, resources included in the biomass feed-in tariff are listed in the Biomass Ordinance (Biomasseverordnung).

${ }^{34}$ Schmidt et al. (2016); Haelg et al. (2018).

${ }^{35}$ Jacobs (2012); REN21 (2016).

${ }^{36}$ See Hettich (2021).

${ }^{37}$ Jacobsson and Lauber (2006).

${ }^{38}$ Schmela and Kreutzmann (2001).
} 
active in the market. ${ }^{39}$ Yet, these existing firms were predominantly manufacturers of building-integrated PV (BIPV) modules.

Fourth, the policymaking process in Switzerland includes a public consultation process (Vernehmlassungsverfahren) during which interested associations and interest groups as well as individuals and firms may comment on the draft of every new law or ordinance. The ministry in charge of the proposed policy then compiles a report summarizing the participants' concerns about and approval of the consultation process. These documents are publicly available and add to the good availability of data on the policymaking process in Switzerland.

\subsection{Method and Sampling}

We proceeded in two steps. First, we conducted comprehensive desk research, scanning academic literature and policy documents, such as draft and final versions of the German Renewable Energy Sources Act (EEG), the Swiss Energy Act (EnG), and the corresponding Energy Ordinance (EnV), transcripts of parliamentary debates and of meetings by the parliamentary energy commissions, statements on the public consultation process, and public and technical reports cited during the parliamentary debates.

Second, we conducted interviews with bureaucrats, parliamentarians, and representatives of industry associations to gain insights into processes not publicly available. We interviewed a sample of 17 persons who were involved in the Swiss policymaking process. Two additional actors preferred to give a written statement by e-mail rather than being interviewed. We used theoretical sampling to identify relevant interview partners, ${ }^{40}$ who were then contacted via e-mail. The interviews were conducted in person or by phone, lasted between 30 and $120 \mathrm{~min}$, and were transcribed.

\section{Evolution of the Feed-In Tariff Design in Germany and Switzerland}

This section summarizes the results of this study. We start with a section (4.1) on the implementation of the feed-in tariff as a policy instrument to support RE technologies in Switzerland and on the transfer of the instrument design from Germany. This is followed by Sect. 4.2 presenting more detailed results on the two technologies biomass and solar PV, respectively. All sections are subdivided into two parts presenting how and why the feed-in tariff design came about.

\footnotetext{
${ }^{39}$ IEA (2009).

${ }^{40}$ Eisenhardt (1989).
} 


\subsection{Feed-In Tariff Implementation}

In 1999, the Swiss parliament implemented the EnG following the addition of the Energy Article to the Swiss constitution after a popular vote. The Energy Article requires the federal government to "establish principles on the use of local and RE sources and on the economic and efficient use of energy". ${ }^{41}$ The EnG replaced the earlier Resolution on Energy Use, incorporating the principle of supporting RE with guaranteed grid access and a tariff reflecting the cost of electricity from new conventional power production plants. Requests by a minority of members of the Social Democratic Party (SP) and the Green Party (GP) to offer a cost-covering remuneration for solar PV and wind power were dismissed at that time.

In a referendum in 2002, the majority of Swiss voters rejected a framework law for the liberalization of the Swiss electricity market against which the labor unions, supported by French-speaking SP representatives, had taken the optional referendum. After the vote, however, the European Union continued to push for electricity market liberalization in Switzerland. A new draft was therefore elaborated by the Swiss Federal Office of Energy (SFOE) and published by the Federal Council in 2004 and subsequently dealt with by the two chambers of parliament. In this context, SP parliamentarians, backed by RE industry associations and the GP, seized the window of opportunity opened by the first rejection of the market liberalization law to push for an EnG revision including comprehensive support for RE. This had become feasible because the left-wing parties threatened to relaunch a referendum against market liberalization, aided by complementary developments, such as blackouts in California and an increasing oil price, which caused many center and rightwing parliamentarians to consider RE as a means of ensuring the security of supply. Importantly, experiences in other countries where RE already received policy support-specifically Germany-were also invoked to argue in favor of RE in Switzerland. Supportive center and right-wing parliamentarians, particularly those with relations to technology users or suppliers, were specifically concerned by the Swiss industry losing market shares. Hansjörg Walter (National Councilor, Swiss People's Party [SVP], head of the Farmers' Union) stated during the debate in 2005,

We have already lost a lot compared to Germany and Austria, where the support for alternative energies, particularly for biomass, is strong. ${ }^{42}$

Yves Christen (National Councilor, Radical Democratic Party (FDP), President of Swissolar) stated during the same debate,

In Germany, roughly 150,000 jobs have been created since the introduction of the cost-based feed-in tariff. This is the last moment for us to enter this market by creating a domestic market and by promoting access to renewable energies. ${ }^{43}$

\footnotetext{
${ }^{41}$ Federal Constitution of 18 April 1999 of the Swiss Confederation, Art. 89 para. 2.

${ }^{42}$ Walter, Plenary Session, OB NC 2005, 1091.

${ }^{43}$ Christen, Plenary Session, OB NC 2005, 1078.
} 
In the first draft of the new EnG, the SFOE and the Federal Council included a set of different instruments to support RE, including voluntary quotas and competitive auctions. However, the parliament finally opted, in principle, for the adoption of a feed-in tariff in 2007 after many rounds of debates. ${ }^{44}$ The SP and GP parliamentary groups, who unanimously voted in favor of the feed-in tariff, did not have a majority in the parliament. Yet, they were supported by a great number of parliamentarians from other parties who were, besides others, representatives of farmers and businesses and saw opportunities for their constituents in comprehensive RE support. The KEV was thus adopted. The experience in Germany was invoked by many proponents to support their choice. Specifically, they referred to Germany as an example where the feed-in tariff proved to be effective in increasing RE deployment. Two RE associations (Renewable Energy Agency (AEE) and Holzenergie Schweiz) stated during the public consultation process,

The cost-based feed-in tariff is evidentially (see the example of Germany and others) the only truly effective instrument for the promotion of renewable energies. ${ }^{45}$

Adrian Stiefel (Head of Climate and Energy Policy at WWF) stated in an interview,

[We] had a look at Germany and some other countries to see what [instrument] they used, how effective were the different instruments, where was [RE deployment] increased, where did we see the desired development, and finally where could we see scalability. We soon realized that the feed-in tariff was the right instrument for our situation.

Roger Nordmann (National Councilor, SP) stated in an interview,

Germany was a very important role model because it showed that this scheme could achieve [broad RE deployment].

Martin Bäumle (National Councilor, Green Liberal Party [GLP]) stated during the parliamentary debate,

The feed-in model is an internationally well-proven model, and the majority of our neighboring countries and competitors in this technology sector have this model. RE capacity additions, for instance, in Germany, prove that it is successful. ${ }^{46}$

Once the parliament had decided on the policy instrument, it discussed the specificities of the feed-in tariff to be written into the EnG. One such discussion emerged around the RE technologies to be included in the feed-tariff, specifically around the question of whether solar PV should be removed from the scheme. On this issue, the bill shuttled between the two chambers of parliament many times and triggered heated debates. Finally, a compromise was achieved, linking the amount of support for solar PV to its cost. This meant that solar PV would only receive little support while its cost was still very high, but that this support could grow when the cost fell below predefined thresholds. Specifically, the share of support for individual

\footnotetext{
${ }^{44}$ Haelg et al. (2020).

${ }^{45}$ AEE (2004); HES (2004).

${ }^{46}$ Bäumle, Plenary Session, OB NC 2005, 1089.
} 
technologies was limited to $50 \%$ for small hydropower and 30\% for other technologies, while solar PV could receive between $5 \%$ and $30 \% .{ }^{47}$ Interestingly, proponents of both opinions looked at Germany for arguments. On the one hand, actors in favor of entirely excluding solar PV argued that the solar PV boom in Germany was inefficient, as the technology's cost was still quite high, and were thus afraid to incur high costs. On the other hand, actors in favor of including solar PV argued that the development in Germany had created many jobs in the solar PV industry and that the cost for solar PV was declining at a high rate. David Stickelberger (Managing Director of Swissolar) stated in an interview,

The opposite coalition certainly used [Germany as an example]. We used it, too. We pointed out that in Germany, the market started to grow and the cost decreased. It started at 1 euro per $\mathrm{kWh}$ or even more and then decreased considerably.

Yves Christen (National Councilor, FDP, President of Swissolar) stated in an interview,

[To convince others to include solar PV], I talked a lot about the small and medium enterprises. The idea was to show that in Germany they had created thousands of jobs.

Another discussion emerged around the surcharge imposed on electricity consumers to finance the feed-in tariff. Unlike in Germany where the consumer surcharge was uncapped, that is, limited only by the number of installations applying for the feed-in tariff, the Swiss parliamentarians decided very early on in the policymaking process to cap the surcharge and thus set a limit to the number of installations that could be supported. The main debate then emerged around the level at which the surcharge should be capped. SP and GP parliamentarians supported a high ceiling, while important representatives of the SVP, FDP, and CVP, especially in the National Council, argued for a lower cap. Finally, the Council of States compromised on a medium ceiling of $0.6 \mathrm{Rp} . / \mathrm{kWh}$, and the National Council followed suit. Here, the proponents of a low cap used Germany as an example where unlimited RE support had led to a high EEG charge and thus to high electricity prices for consumers. Rolf Hegetschweiler (National Councilor, FDP) stated during the debate,

\footnotetext{
We are ready to invest a lot of money in the RE deployment. The consumer will have to pay for this. We should not be surprised if we experience the same as Germany, for instance: the experience that [the electricity market] is liberalized, but that electricity prices finally rise because we pass the surcharge on to the consumer. ${ }^{48}$
}

Related to the consumer surcharge ceiling, the parliament decided to substantially exempt electricity-intensive businesses from the consumer surcharge. With the issue being largely uncontested, the main discussion emerged around the question of whether these businesses should be entirely or only substantially exempted and thus around fairness. While other countries, including Germany, had implemented

\footnotetext{
${ }^{47}$ EnG Art. 7a (2009).

${ }^{48}$ Hegetschweiler, Plenary Session, OB NC 2006, 1784.
} 
a similar design element in their feed-in tariff schemes, they were not used as an argument in favor of or against the exemption in parliament. Yet, SFOE representatives stated in a commission meeting that they had used the German exemption for electricity-intensive businesses as a blueprint to formulate their proposal, which was adopted by the parliament with few amendments.

Finally, the EnG amendment including a technology-specific feed-in tariff for RE generation, as adopted by the federal parliament, was implemented in 2009. Further design specificities of the instrument, such as the individual tariffs, were left to the SFOE and the Federal Council, who defined them separately in the EnV.

\subsection{Feed-In Tariff Designs Specific to Individual Technologies}

One of the key design elements of a feed-in tariff is how it supports specific technologies and their applications in different markets. ${ }^{49}$ Here, we analyze the two specific technologies biomass and solar PV to understand which design elements were transferred and which were accommodated.

While the new EnV was implemented along with the amended EnG in 2009, preparatory work on it started much earlier, in 2006, in fact before the EnG was approved by parliament. The subscription process for installations to receive the feed-in tariff opened in April 2008, even though the feed-in tariff was not introduced until January 2009. The surcharge cap was reached within 6 months, that is, before the feed-in tariff had become active. ${ }^{50}$ The consumer surcharge has therefore been increased several times since the EnG's implementation in 2009 to reduce the number of projects on the waiting list.

As parliament was pushing for a prompt implementation of the feed-in tariff, the deadlines for the SFOE to draft the specific designs for the individual technologies were short. For this reason and because Germany had already gained experience with its feed-in tariff design, the policymakers at the SFOE analyzed with interest what was working and what was not in the neighboring country, including design elements related to specific technologies and applications. Michael Kaufmann (Head of Renewable Energies, SFOE) stated in an interview,

We analyzed a lot and had many experts from Germany who showed us how things worked and also did not work. We tried to avoid many misdirected incentives that were present in Germany.

\footnotetext{
${ }^{49}$ Schmidt et al. (2016); Haelg et al. (2018).

${ }^{50}$ SFOE (2008).
} 


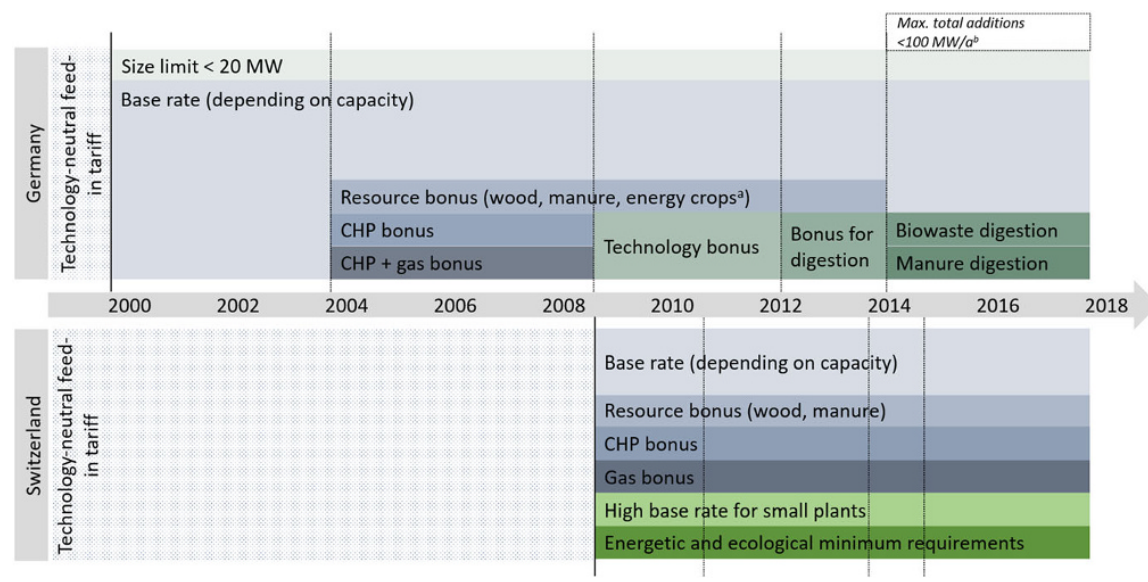

Fig. 2 Design elements of the biomass feed-in tariff in Germany (top) and Switzerland (bottom). The elements that only appear in one country's design are colored in green. The vertical black lines disclose the major amendments of the policies in Germany and Switzerland. ${ }^{a} E n e r g y$ crops (nachwachsende Rohstoffe [NaWaRo]) are crops specifically grown for power generation; ${ }^{b}$ the total gross additions are limited to $100 \mathrm{MW}$, and the tariffs provided to biomass installations were adapted to achieve this goal

\subsubsection{Specific Design of the Biomass Feed-In Tariff}

Supporting biomass was never contested either in Switzerland or in Germany due to the farmers' strong lobby and the relatively centralized and dispatchable nature of biomass power production. As Rudolf Rechsteiner (National Councilor, SP) stated in an interview,

This may sound exotic today, but at that moment, biomass, biogas, and geothermal power formed the majority in parliament [leading to the adoption of the feed-in tariff].

Work on the design of the Swiss biomass feed-in tariff started in 2006, with the finalized tariffs implemented in the context of the EnV amendment in 2009. The Swiss tariff structure was similar to the structure in place in Germany at the time (see Fig. 2, below). It consisted of a base rate depending on the installation's electric capacity complemented by bonuses for more costly feedstocks, combined heat and power technology, and the electrification of biogas. In Switzerland, the base rate differentiated between capacities lower than $50 \mathrm{~kW}$ and capacities between $50 \mathrm{~kW}$ and $100 \mathrm{~kW}$. It was considerably higher than in Germany, where the base rate was the same for all installations below $150 \mathrm{~kW}$. The tariff structure persisted throughout subsequent amendments of the $\mathrm{EnV}$ even though some actors made advances to add a high bonus for entirely manure-based installations. Additionally, the biomass installations supported by the feed-in tariff had to fulfill minimum energetic and ecological requirements, such as the use of the process heat for feedstock drying and the exclusion of primary renewable feedstock from the support. 
The design of the Swiss biomass feed-in tariff displays striking similarities to the German design in place at the time when the Swiss version was drafted. As Bruno Guggisberg (SFOE employee in charge of biomass) stated in an interview,

We said, 'Let's do something for biomass according to the [German] system, with a base rate and bonuses.'

"The deadline was so short [...], we did not need to reinvent the wheel. So we looked across the border [...] mainly to Germany."

We looked at the EEG specifications [...] and decided to take [them] and see how they can be adapted to Switzerland.

The design of the Swiss biomass feed-in tariff featured two minor deviations from the German design. First, biomass installations needed to fulfill energetic and ecological minimum requirements to be eligible for support. This was due to the increasing number of installations directly using primary RE crops for electricity production in Germany. Such installations led to decreasing social acceptance for biomass installations in Germany and to the implementation of these minimum requirements in Switzerland. As Bruno Guggisberg (SFOE employee in charge of biomass) stated in an interview,

Those installations using energy crops, we did not want to support those. [...] We wanted to introduce ecological minimum requirements to prevent these [installations] which do not fulfill those requirements.

As Stefan Mutzner (Managing Director of Ökostrom Schweiz) stated in an interview,

[Energy crop plants] do not make sense in Switzerland. In Germany, they served to avoid a surplus of certain grains and to use fallow land to grow energy crops for biogas plants. We don't have that in Switzerland. ${ }^{51}$

Second, small installations receive considerably higher base rates. As Bruno Guggisberg (SFOE employee in charge of biomass) stated in an interview,

The Germans had different classifications. They also had larger installations. We felt that those did not fit for Switzerland.

According to the RE statistics, the existing installations were mostly $30 \mathrm{~kW}, 50 \mathrm{~kW}$, $80 \mathrm{~kW}$.

This is confirmed by an industry representative who, however, stated that small plants expand their capacity nowadays and newly-built plants are all above $200 \mathrm{~kW}$.

\subsubsection{Specific Design of the Solar PV Feed-In Tariff}

As outlined in Sect. 4.1, the support for solar PV was highly contested in the parliamentary debate that led to the introduction of the feed-in tariff in Switzerland. In 2009, the specific design of the solar PV feed-in tariff initially differentiated between rooftop, open-space, and building-integrated solar PV and varied with the

\footnotetext{
${ }^{51}$ Swiss agriculture supplies only $64 \%$ of the country's gross food consumption, Walser (2013).
} 
installed capacity. The tariffs were continuously adapted to the solar PV price reductions. With the amendment of 2014, a one-off investment grant for smallscale rooftop installations was introduced. Since then, installations below $10 \mathrm{~kW}$ no longer obtain a feed-in tariff but a one-off investment grant consisting of a base rate and a capacity-dependent rate. Owners of installations between $10 \mathrm{~kW}$ and $30 \mathrm{~kW}$ have the choice between the feed-in tariff and the investment grant. Finally, the most recent amendment in 2015 granted the same tariff for rooftop and open-space installations.

Similar to the German solar PV feed-in tariff design, the Swiss design differentiated between rooftop and open-space installations. This is intriguing since the support for open-space installations was in fact disfavored. As David Stickelberger (Managing Director of Swissolar) stated in an interview,

Even more than today, we saw open-space installations as compromising the reputation [of solar PV].

We did not have special interest in the open-space installations. I remember that the Federal Office [of Energy] introduced it, and we thought, do it if you want to.

In later amendments, both countries adapted the design to provide equal tariffs to (large-scale) rooftop and open-space installations. In Switzerland, the distinction between large- and small-scale was abolished in that very small-scale installations no longer received a feed-in tariff. The rationale behind consolidating the two categories was the investment cost for the different installation types, which had largely converged in previous years and therefore did not require further tariff differentiation. $^{52}$

Besides the similarities, the Swiss solar PV feed-in tariff design exhibits several differences from the German case (Fig. 3). First, the small-scale investment grant was introduced as a reaction to the high number of small-scale rooftop solar PV installations on the waiting list to receive the feed-in tariff. The waiting list was a direct result of the investment cap for solar PV.

Second, unlike the German feed-in tariff, the Swiss solar PV feed-in tariff has always extensively supported BIPV installations. In fact, Switzerland was the home of a small BIPV industry that emerged in the 1990s as a result of the strong research and development support policies in this sector. This Jenny (State Councilor, SVP) stated in a debate in 2007 ,

[The BIPV] market grows very quickly: the revenues increase every year by $45 \%$. [...] But sadly the [Swiss] products are only exported; sadly they only go abroad - we need a domestic market. ${ }^{53}$

Urs Wolfer (SFOE employee in charge of solar PV) stated in an interview,

If you never start to push [building-integrated PV], nothing is ever going to be developed. Therefore, we set this incentive.

\footnotetext{
${ }^{52}$ SFOE (2014).

${ }^{53}$ Jenny, Plenary Session, OB CoS 2007, 52.
} 


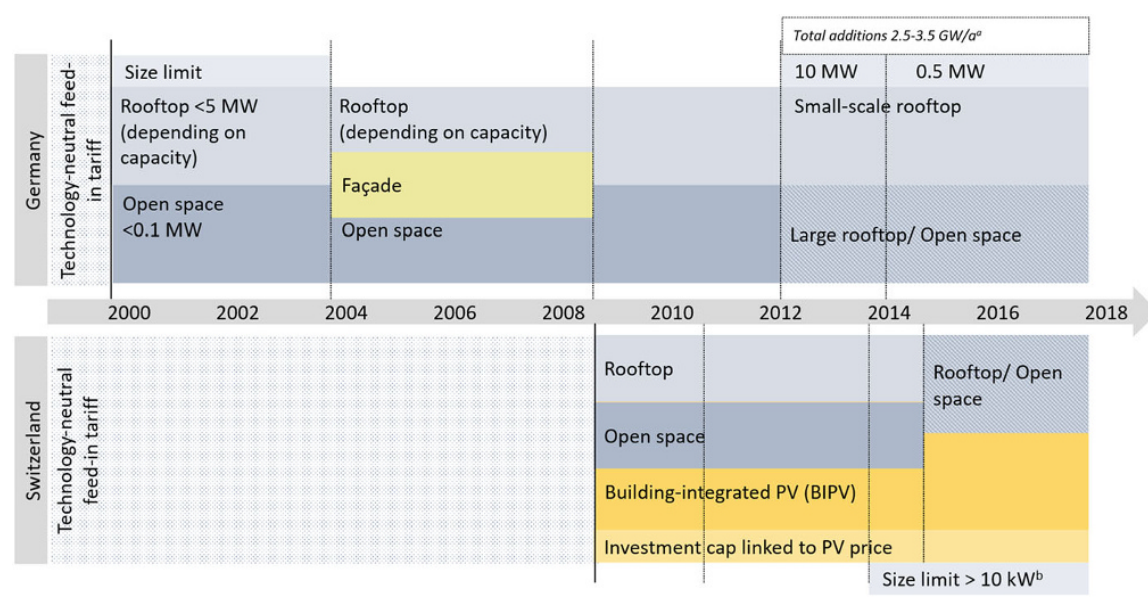

Fig. 3 Design elements of the solar PV feed-in tariff in Germany (top) and Switzerland (bottom). The elements that only appear in one country's design are colored in yellow. The vertical black lines disclose the major amendments of the policies in Germany and Switzerland. ${ }^{\text {a }}$ The total gross additions are limited to 2.5-3.5 GW (2012-2014) and 2.5 GW (since 2014), respectively, and the tariffs provided to solar PV installations adapted to achieve this goal; ${ }^{b}$ since 2014 , solar PV installations below $10 \mathrm{~kW}$ no longer obtain a feed-in tariff but a one-off investment grant consisting of a base rate and a capacity-dependent rate. Owners of installations between $10 \mathrm{~kW}$ and $30 \mathrm{~kW}$ have the choice between the feed-in tariff and the investment grant

\section{David Stickelberger (Managing Director of Swissolar) stated in an interview,}

Our stance was always consistent in that we wanted the BIPV tariff. [BIPV] was the USP [unique selling point] of the Swiss PV industry and even an export good in the initial period of the feed-in tariff.

The other argument was the social acceptance. Our position was to fulfill higher aesthetic standards, much higher than [those] abroad.

This design feature was introduced for two reasons. First, the Swiss PV industry lobbied to include their main product, BIPV modules, in the policy scheme. Therefore, this design element originated from domestic factors that influenced pathdependent policymaking and therefore from emerging actors. Second, this design feature was also introduced due to concerns about losing shares in the transnational BIPV market.

Finally, even though revisions of the EnV and thus the tariffs for the individual technologies and installations were decided upon only by the Federal Council, they still underwent a public consultation process. Stakeholders opposing high tariffs for solar PV even used Germany as an example to solicit for lower tariffs. Urs Näf (Head of Energy Policy, Economiesuisse) stated in an interview,

[Germany] was the most important case for us to obtain reference prices. We always analyzed whether the Swiss prices were far from their [Germany's] prices. I remember having noticed that solar PV received double the amount in Switzerland than in Germany at one point. [...] We tried to pressure for lower tariffs, but it did not work. [...] Therefore, solar PV was hopelessly overpaid for very long. 


\section{Discussion and Conclusion}

A considerable body of research has analyzed how policies are transferred from one country to another. However, very few studies have examined how and why the design of a transferred policy is accommodated upon adoption in the recipient country. In this chapter, we have focused on the Swiss feed-in tariff policy instrument and explored which of this instrument's design elements were transferred and which were accommodated upon adoption and how. We studied the evolution of the Swiss feed-in tariff in general as well as its specific design for biomass and solar PV technologies. We find that Swiss policymakers have drawn much from the experience with the feed-in tariff in Germany. On the instrument level, policymakers were influenced by this experience and the resulting boom in RE installations and its industry. For biomass, where similar technology users and suppliers exist in both countries, the design of the feed-in tariff was adapted to the Swiss context only to a limited extent. For solar PV, however, the design has been largely accommodated to the Swiss context, on the one hand, due to learning from the German experience and, on the other hand, due to the different industry base present in the two countries. We hence find that technology-related actors take an important role in the policy transfer process. This chapter thus complements the existing literature on policy diffusion and transfer, with a focus on instrument design and its accommodation upon adoption.

These findings have policy implications on a broader technology governance level, especially given the increasing role of technology in both creating and solving problems in various policy fields, ${ }^{54}$ specifically climate and energy policy. The diffusion of policy instruments is more likely to happen without a specific design accommodation between jurisdictions if they share the same technology-related actor base. This finding allows us to speculate about other sectors in Switzerland that need decarbonization. For instance, policy transfer without major accommodation is likely in the field of low-carbon heating technologies between the cantons in Switzerland or between Switzerland and Austria. These jurisdictions not only share a similar current technology stock and suppliers, they are also host to important manufacturers of low-carbon heating technologies, such as heat pumps and woodfired heating devices. In contrast, the accommodation of design elements can be expected between jurisdictions with different technology-related actor bases. For instance, policy transfer with major accommodations between Switzerland and its larger neighboring countries is likely regarding electric mobility, which will probably become relevant in the very near future. While France, Germany, and Italy are all home to important automotive industries with their own interests regarding electric mobility, such actors are lacking in Switzerland. These implications are important for policymakers, as they may help them foresee technology-related differences in the positions of their actor bases regarding policy design elements.

\footnotetext{
${ }^{54}$ Jaffe et al. (2002).
} 
This may help policymakers identify actors with similar interests as well as pinpoint issues where resources may be bundled to obtain the desired policy output.

The contributions of our study are fourfold. First, we unpack and analyze the policy design elements of a deployment policy and their diffusion from one country to another and, hence, expand the focus of the policy diffusion and transfer literatures to these micro-level elements. Second, we show the influence of technologyrelated actors in policy adoption and accommodation. These actors initially only emerge upon (early) technology deployment and therefore coevolve with policy. ${ }^{55}$ Third, we contribute to the literature on RE policies with an in-depth analysis of the Swiss feed-in tariff, specifically for biomass and solar PV technologies. Fourth, and more broadly, we contribute to discussions about designing policies that are effective in the long run, for example, by creating positive policy feedback from targeted or nurtured actors. ${ }^{56}$

To test our results, future research should expand our approach to other cases, that is, more RE technologies, other countries, or even other policy fields. Quantitative studies could analyze to what extent our results are generalizable. This is however tricky since comparatively measuring the dependent variable, policy design output, is challenging ${ }^{57}$ and has only recently been tackled. ${ }^{58}$

\section{References}

AEE (2004) Vernehmlassungsantwort - Vernehmlassung AEE zum Stromversorgungsgesetz. Agentur für erneuerbare Energien und Energieeffizienz

Benson D, Jordan A (2011) What have we learned from policy transfer research? Dolowitz and Marsh Revisited. Polit Stud Rev 9:366-378

Berry FS, Berry WD (2014) Innovation and diffusion models in policy research. In: Sabatier PA, Weible CM (eds) Theories of the policy process, 3rd edn. Westview Press, Boulder/CO, pp 307-359

Biesbroek GR, Swart RJ, Carter TR, Cowan C, Henrichs T, Mela H, Morecroft MD, Rey D (2010) Europe adapts to climate change: comparing national adaptation strategies. Glob Environ Change 20:440-450

Biesenbender S, Tosun J (2014) Domestic politics and the diffusion of international policy innovations: how does accommodation happen? Glob Environ Change 29:424-433

BMWi (2019) Zahlen und Fakten - Energiedaten. Bundesministerium für Wirtschaft und Energie, Berlin

Braun D, Gilardi F (2006) Taking "Galton's Problem" seriously: towards a theory of policy diffusion. J Theor Polit 18:298-322

Busch P-O, Jörgens H, Tews K (2005) Regulatory instruments: the making of a new international environmental regime. AAPSS Ann 598:146-167

\footnotetext{
${ }^{55}$ Schmidt and Sewerin (2017).

${ }^{56}$ Voss et al. (2009); Jordan and Matt (2014); Capano and Woo (2017).

${ }^{57}$ Schaffrin et al. (2015).

${ }^{58}$ Schmidt and Sewerin (2019).
} 
Capano G, Woo JJ (2017) Resilience and robustness in policy design: a critical appraisal. Policy Sci 50:355-382

Carley S, Davies LL, Spence DB, Zirogiannis N (2018) Empirical evaluation of the stringency and design of renewable portfolio standards. Nat Energy 3:754-763

Cashore B, Howlett M (2007) Punctuating which equilibrium? Understanding thermostatic policy dynamics in pacific northwest forestry. Am J Pol Sci 51:532-551

Cheon A, Urpelainen J (2013) How do competing interest groups influence environmental policy? The case of renewable electricity in industrialized democracies, 1989-2007. Polit Stud 61:874-897

Couture T, Gagnon Y (2010) An analysis of feed-in tariff remuneration models: implications for renewable energy investment. Energy policy 38:955-965

Dolowitz DP, Marsh D (1996) Who learns what from whom: a review of the policy transfer literature. Polit Stud 44:343-357

Dumas M, Rising J, Urpelainen J (2016) Political competition and renewable energy transitions over long time horizons: a dynamic approach. Ecol Econ 124:175-184

Ebers A, Wüstenhagen R (2017) Local acceptance of wind energy in Switzerland, Estonia and Ukraine. A cross-country analysis based on choice experiments. Universität St. Gallen, St. Gallen

Eisenhardt KM (1989) Building theories from case study research. Acad Manag Rev 14:532-550

Gilardi F, Füglister K (2008) Empirical modeling of policy diffusion in federal states: the dyadic approach. Swiss Polit Sci Rev 14:413-450

Haelg L, Waelchli M, Schmidt TS (2018) Supporting energy technology deployment while avoiding technological lock-in. Environ Res Lett 13:104011

Haelg L, Sewerin S, Schmidt TS (2020) The role of actors in the policy design process: introducing design coalitions to explain policy output. Policy Sci 53:309-347

HES (2004) Vernehmlassungsantwort - Bundesgesetz über die Stromversorgung und Revision des Elektrizitätsgesetzes. Holzenergie Schweiz, Zurich

Heselhaus S (2021) The quest for the future energy mix in the EU and in Switzerland. In: Hettich P, Kachi A (eds) Swiss energy governance. Springer, New York, pp 43-60

Hettich P (2021) Governing decentral energy systems. In: Hettich P, Kachi A (eds) Swiss energy governance. Springer, New York, pp 155-170

Holzinger K, Knill C, Sommerer T (2011) Is there convergence of national environmental policies? An analysis of policy outputs in 24 OECD countries. Environ Polit 20:20-41

Hoppmann J, Huenteler J, Girod B (2014) Compulsive policy-making - the evolution of the German feed-in tariff system for solar photovoltaic power. Res Policy 43:1422-1441

IEA (2009) National Survey Report of PV power applications in Switzerland 2008. International Energy Agency, Paris

Jacobs D (2012) Renewable energy policy convergence in the EU - the evolution of feed-in tariffs in Germany, Spain and France. Ashgate Publishing Limited, Farnham

Jacobs D (2014) Policy invention as a process of evolutionary tinkering and codification: the emergence of feed-in tariffs for renewable electricity. Environ Polit 25:755-773

Jacobsson S, Lauber V (2006) The politics and policy of energy system transformation-explaining the German diffusion of renewable energy technology. Energy Policy 34:256-276

Jaffe AB, Newell RG, Stavins RN (2002) Environmental policy and technological change. Environ Resour Econ 22:41-70

Jaffe AB, Newell RG, Stavins RN (2005) A tale of two market failures: technology and environmental policy. Ecol Econ 54:164-174

Jordan A, Huitema D (2014) Innovations in climate policy: the politics of invention, diffusion, and evaluation. Env Polit 23:715-734

Jordan A, Matt E (2014) Designing policies that intentionally stick: policy feedback in a changing climate. Policy Sci 47:227-247

Kemp R, Pontoglio S (2011) The innovation effects of environmental policy instruments - a typical case of the blind men and the elephant? Ecol Econ 72:28-36 
Lehmann P, Söderholm P (2018) Can technology-specific deployment policies be cost-effective? The case of renewable energy support schemes. Environ Resour Econ 71:475-505

Markard J, Suter M, Ingold K (2016) Socio-technical transitions and policy change - advocacy coalitions in Swiss energy policy. Environ Innov Soc Trans 18:215-237

Marsh D, Sharman JC (2009) Policy diffusion and policy transfer. Policy Stud 30:269-288

Matisoff DC (2008) The adoption of state climate change policies and renewable portfolio standards: regional diffusion or internal determinants? Rev Policy Res 25:527-546

Matisoff DC, Edwards J (2014) Kindred spirits or intergovernmental competition? The innovation and diffusion of energy policies in the American states (1990 - 2008). Environ Polit 23:795-817

Mitchell C (2000) The England and Wales Non-Fossil fuel obligation: history and lessons. Annu Rev Energy Environ 25:285-312

Newmark AJ (2002) An integrated approach to policy transfer and diffusion. Rev Policy Res 19:151-178

Polzin F, Egli F, Steffen B, Schmidt TS (2019) How do policies mobilize private finance for renewable energy? - a systematic review with an investor perspective. Appl Energy 236:1249-1268

REN21 (2005) Renewables 2005 Global Status Report. REN21 Secretariat, Paris

REN21 (2012) Renewables 2012 Global status report. REN21 Secretariat, Paris

REN21 (2016) Renewables 2016 Global status report. REN21 Secretariat, Paris

Schaffer LM, Bernauer T (2014) Explaining government choices for promoting renewable energy. Energy Policy 68:15-27

Schaffrin A, Sewerin S, Seubert S (2015) Toward a comparative measure of climate policy output. Policy Stud J 43:257-282

Schmela M, Kreutzmann A (2001) Marktwachstum gewinnt an Fahrt. Phot. Das SolarstromMagazin 4:12-15

Schmidt TS, Sewerin S (2017) Technology as a driver of climate and energy politics. Nat Energy $2: 17084$

Schmidt TS, Sewerin S (2019) Measuring the temporal dynamics of policy mixes - an empirical analysis of renewable energy policy mixes' balance and design features in nine countries. Res Policy 48:103557

Schmidt TS, Battke B, Grosspietsch D, Hoffmann VH (2016) Do deployment policies pick technologies by (not) picking applications? - a simulation of investment decisions in technologies with multiple applications. Res Policy 45:1965-1983

Sonnberger M, Ruddat M (2017) Local and socio-political acceptance of wind farms in Germany. Technol Soc 51:56-65

Stadelmann M, Castro P (2014) Climate policy innovation in the South - domestic and international determinants of renewable energy policies in developing and emerging countries. Glob Environ Change 29:413-423

Stokes LC (2013) The politics of renewable energy policies: the case of feed-in tariffs in Ontario, Canada. Energy Policy 56:490-500

Stoutenborough JW (2008) Encouraging pollution-free energy: the diffusion of state net metering policies. Soc Sci Q 89:1230-1251

Strebel F (2011) Inter-governmental institutions as promoters of energy policy diffusion in a federal setting. Energy Policy 39:467-476

Swiss Federal Office of Energy (2008) Das neue Fördersystem für grünen Strom stösst an seine Grenzen. Press release, 28 November 2008

Swiss Federal Office of Energy (2014) Revision der Energieverordnung per 1. Januar 2015. Press release, 05 November 2014

Swiss Federal Office of Energy (2019) Schweizerische Gesamtenergiestatistik 2018. Swiss Federal Office of Energy, Bern

Tews K, Busch P-O, Jörgens H (2003) The diffusion of new environmental policy instruments. Eur J Polit Res 42:569-600 
Van Benthem A, Gillingham K, Sweeney J (2008) Learning-by-doing and the optimal solar policy in California. Energy J 29:131-151

Voss JP, Smith A, Grin J (2009) Designing long-term policy: rethinking transition management. Policy Sci 42:275-302

Walser B (2013) Hat die Schweiz genügend Boden, um alle satt zu machen? Tages-Anzeiger, 21 November 2013

Wiser R, Namovicz C, Gielecki M (2007) The experience with renewable portfolio standards in the United States. Electr J 20:8-20

Leonore Haelg is Scientific Collaborator at Zurich University of Applied Sciences (ZHAW), Research Group for Renewable Energy, Institute of Natural Resource Sciences, Campus Grüental, Wädenswil, Switzerland. She conducted her PhD thesis with the Energy and Technology Policy Group at the Department of Humanities, Social and Political Sciences at ETH Zurich, Zurich, Switzerland

Tobias S. Schmidt is Associate Professor at the Department of Humanities, Social and Political Sciences at ETH Zurich, Zurich, Switzerland and head of the Energy and Technology Policy Group.

Sebastian Sewerin is a senior researcher and a lecturer with the Energy and Technology Policy Group at the Department of Humanities, Social and Political Sciences at ETH Zurich, Zurich, Switzerland.

Open Access This chapter is licensed under the terms of the Creative Commons Attribution 4.0 International License (http://creativecommons.org/licenses/by/4.0/), which permits use, sharing, adaptation, distribution and reproduction in any medium or format, as long as you give appropriate credit to the original author(s) and the source, provide a link to the Creative Commons license and indicate if changes were made.

The images or other third party material in this chapter are included in the chapter's Creative Commons license, unless indicated otherwise in a credit line to the material. If material is not included in the chapter's Creative Commons license and your intended use is not permitted by statutory regulation or exceeds the permitted use, you will need to obtain permission directly from the copyright holder. 